\title{
RELAÇÕES DE TRABALHO E DESIGUALDADES DE GÊNERO NA INDÚSTRIA TÊXTIL E DE CONFECÇÕES DO NORDESTE
}

\author{
Elaine Bezerra * \\ Roseli de Fátima Corteletti** \\ Iara Maria de Araújo ***
}

\begin{abstract}
O objetivo deste artigo é analisar duas realidades de trabalho marcadas pela flexibilidade e precariedade, e com presença de uma força de trabalho intensiva de mulheres, na Região Nordeste do Brasil. A primeira, envolve mulheres que atuam como costureiras externas em facções domiciliares do Polo de Confecções do Agreste Pernambucano. Na segunda, temos o protagonismo feminino interno à produção têxtil no município de Jardim de Piranhas-RN. A divisão sexual do trabalho apresenta uma centralidade em ambas as experiências, seja reforçando os lugares clássicos que homens e mulheres ocupam na produção e na reprodução, seja apresentando questões novas. Foram realizadas visitas e entrevistas nos dois contextos produtivos, o que permitiu um contato com as experiências de trabalho das mulheres. No primeiro caso, o trabalho domiciliar significa a busca por autonomia e liberdade, no qual temos também a entrada dos homens na atividade de costura. No segundo, as mulheres tornam-se proprietárias de teares e a presença dos homens ainda é pequena. No entanto, esses fatores não repercutiram positivamente nas desigualdades de gênero, uma vez que as tarefas domésticas permanecem inalteradas e, mesmo com as longas jornadas de trabalho, elas não percebem as condições desiguais.

Palavras-chave: Indústria têxtil e de confecções. Trabalho feminino. Desigualdades de gênero. Informalidade. Precariedade do trabalho.
\end{abstract}

\section{INTRODUÇÃO}

As mudanças atuais no mundo do trabalho fazem com que a informalidade apareça de braços dados com formas diversas de trabalho flexível, como é o caso da terceirização, subcontratação, o trabalho doméstico e o trabalho de cuidado de outras pessoas, nos quais as mulheres representam a maior parte da força de trabalho. Estas formas manifestam-se em contratos por conta própria, parcial ou por tempo determinado, intermitente, home office, entre outras modalidades, as quais, além de não garantir direitos sociais aos trabalhadores(as), transferem para eles(as) o ônus da reprodução da força de trabalho. Sendo responsável pela realização de atividades dentro e fora de casa,

* Rua Coronel Joaquim Tibúrcio, 831, Apto 401. Heliópolis. Belo Horizonte - Minas Gerais - Brasil. elainemauriciobezerra@gmail.com

https://orcid.org/0000-0002-5326-040X

* * Universidade Federal de Campina Grande (UFCG). Unidade Acadêmica de Ciências Sociais

Rua Aprígio Veloso, 882 - Universitário. Cep: 58428-830. Campina Grande - Paraíba - Brasil. roselicortel@yahoo.com.br https://orcid.org/0000-0002-0277-3344

*** Universidade Regional do Cariri (URCA). Departamento de Educação.

Rua Coronel Antônio Luíz, 1161. Pimenta. Cep: 63105010. Crato - Ceará - Brasil. Iara.mar@terra.com.br

https://orcid.org/0000-0003-2401-6843 ou seja, no espaço produtivo e reprodutivo, a mulher torna-se "duplamente explorada pelo capital” (Antunes, 2000, p. 108-109). No chão da fábrica, é explorada através da produção da mais-valia, que é o trabalho excedente não pago, pelo baixo salário que recebe, pela intensificação e precarização das condições de trabalho, pelos preconceitos e discriminações que sofre e enfrenta no seu dia-a-dia. No entanto, na realização do trabalho doméstico, a mulher é também responsável pela reprodução da força de trabalho do marido e dos filhos. O sistema capitalista, para se reproduzir, necessita da força de trabalho em condições apropriadas para a produção. Essa dupla jornada realizada pela mulher, e, em muitos casos, tripla jornada, não recebe seu devido valor, mas é igualmente importante para a reprodução do sistema capitalista, assim como os demais trabalhos considerados teoricamente improdutivos, como é o caso do setor de serviços em geral (Antunes, 2000).

Sendo assim, o objetivo deste artigo é analisar duas realidades marcadas pela flexibilidade e precariedade do trabalho, e com força de trabalho intensiva de mulheres na re- 
gião Nordeste do Brasil. A primeira, trata do trabalho de mulheres costureiras/proprietárias de pequenas facções ${ }^{1}$ de costura realizada em seus domicílios como terceirizadas para facções maiores, fabricos ${ }^{2}$ ou empresas situadas no Polo de Confecções do Agreste de Pernambuco, mais especificamente no município de Santa Cruz do Capibaribe. A informalidade nas relações de trabalho, baseada nas relações familiares e de confiança, é uma característica marcante desde a origem do Polo até a atualidade. Além disso, as mulheres são as protagonistas no setor de confecções, mas, atualmente, há uma significativa presença dos homens em funções consideradas "femininas", como costurar, lavar, passar ferro, situação que se apresenta como uma novidade no contexto estudado. Na segunda realidade, analisamos o protagonismo feminino dentro da experiência têxtil vivenciada no município de Jardim de Piranhas, localizado no sertão do Seridó, no estado do Rio Grande do Norte.

Essa localidade se especializou na produção de redes de dormir, cobertores, toalhas e panos de prato, tornando-se a principal atividade econômica e gerando trabalho e renda. A produção tem características familiares com alto nível de informalidade, e trabalho subcontratado e terceirizado. A presença das mulheres sempre foi constante, principalmente na fase de acabamento das peças, atividade subcontratada, considerada de baixo valor social e จั baixa remuneração. Nas últimas três décadas, O. Ocorreram mudanças significativas envolvendo essa realidade produtiva, os teares manuais gradativamente foram sendo substituídos จิ por máquinas mecanizadas e mais modernas, $\dot{\sim}$ ao mesmo tempo, os produtos produzidos no

^ 1 As Facções são pequenas unidades produtivas, especia-

$>$ lizadas em determinadas etapas do processo de trabalho.

ธิ Em geral, funcionam na sala ou em uma garagem da casa

e costumam funcionar como terceirizadas para fabricos ou $\geqslant$ empresas de maior porte.

๘ ${ }^{2}$ Segundo Veras de Oliveira (2013, p. 240), "Fabrico é uma

denominação local para as unidades produtivas familia-

J res, com funcionamento em geral domiciliar, de caráter

$\wp$ informal, sendo que gradativamente foram comportando

dimensões variadas". Em geral possuem uma estrutura

mais organizada, com máquinas mais modernas e alguns fabricos são formais. lugar foram sendo diversificados. Se antes a produção se concentrava nas redes de dormir, na atualidade esse artigo é pouco produzido e os panos de prato ocuparam lugar de destaque no município que se tornou um dos maiores produtores do país (Carneiro; Guedes, 2013). A partir de então, com a ascensão desta mercadoria, as mulheres passaram, de forma mais recorrente, a montar seus próprios teares, provocando deslocamentos nas posições que até então ocupavam dentro desse mundo têxtil.

Assim, nossa intenção é problematizar as experiências de mulheres nessas duas realidades produtivas, atentando para a reconfiguração dos seus trabalhos e como isso tem implicado a ressignificação das relações familiares e as desigualdades de gênero. De forma genérica, podemos identificar a existência de "deslocamentos" importantes em relação aos padrões discriminatórios, e, ao mesmo tempo, constatamos uma reedição de antigas relações de desigualdades de gênero. As categorias de patriarcado e da imbricação das relações sociais apresentaram-se como fundamentais para a análise. No estudo, adotaremos, como aporte teórico, os pressupostos da sociologia do trabalho e gênero e, de forma especial, a matriz teórica desenvolvida por Heleieth Saffioti, para pensar a atualidade das desigualdades nos espaços de trabalho, bem como, as transformações atuais no mundo do trabalho.

Contudo, cabe salientar, ainda que de forma introdutória, os conceitos utilizados nas análises das duas experiências empíricas de trabalho. Nesse sentido, nos fundamentamos na ideia de flexibilidade apresentada por Harvey (2006) como um momento da nova fase do capitalismo contemporâneo. Segundo o autor, a acumulação flexível "caracteriza-se pelo surgimento de setores de produção inteiramente novos, novas maneiras de fornecimento de serviços financeiros, novos mercados e, sobretudo, taxas altamente intensificadas de inovação comercial, tecnológica e organizacional" (Harvey, 2006, p. 140).

A terceirização tornou-se uma das prin- 
cipais estratégias flexíveis utilizadas pelas empresas. No Brasil, é uma prática antiga, mas que foi intensificada e reconfigurada pela reestruturação produtiva e políticas neoliberais adotadas a partir de 1990. Torna-se uma ferramenta chave nesta nova configuração do capitalismo, uma vez que, externalizando etapas da produção, as empresas conseguem reduzir os custos com direitos sociais dos trabalhadores/as, ao mesmo tempo em que diminuem o poder de organização coletiva dos mesmos. Nesse sentido, de acordo com Marcelino e Cavalcante (2012), a terceirização é "todo processo de contratação de trabalhadores por empresa interposta, cujo objetivo último é a redução de custos com a força de trabalho e/ou a externalização dos conflitos trabalhistas" (Marcelino; Cavalcante, 2012, p. 338). Entretanto, nas regiões estudadas verificamos que as formas flexíveis de assalariamento, como a informalidade, terceirização, subcontratação ${ }^{3}$ e trabalho domiciliar, fazem parte das relações de trabalho, desde suas origens até a atualidade.

Além disso, torna-se importante destacar o que entendemos por informalidade. Concordando com Lima e Soares, a "informalidade engloba situações analiticamente distintas como economia informal, mercado informal, setor informal e trabalho informal" (Lima; Soares, 2002, p. 3). Contudo, a informalidade nas relações de trabalho possui algumas características definidoras como, por exemplo, a ausência de uma regulação por parte do estado, a ausência de contrato formal de trabalho com registro em carteira e a falta de estabilidade financeira. As experiências aqui evidenciadas sempre foram marcadas pelo trabalho flexível, mas atualmente foram ressignificadas e vem sendo analisadas como modelos de empreendedorismo informal. Observamos, nas duas regiões, que faz parte da cultura local, a vontade de "ser patrão de si mesmo", situação que

3 Nas experiências estudadas, a subcontratação ocorre quando uma facção que trabalha como terceirizada subcontrata algumas atividades de costuras para serem executadas no domicílio de uma outra costureira. Essa ocorre de acordo com o aumento das demandas nas confecçóes de determinadas peças de roupas. garante que não haja desemprego nas regiões, uma vez que é comum a população montar pequenas unidades produtivas para trabalhar de forma "autônoma" ou como terceirizada. Trata-se de um empreendedorismo baseado nas necessidades de sobrevivência da população local, mas que também apresenta elementos novos, como, por exemplo, a resistência de serem contratados e subordinados a outros patrões, uma vez que manter-se na informalidade garante-lhes rendimentos maiores, assim como um certo status social, ainda que a precariedade $^{4}$ seja uma característica marcante, devido à intensificação do trabalho por produtividade.

As pesquisas que subsidiam as reflexões trazidas neste artigo foram desenvolvidas nos municípios de Caruaru, Santa Cruz do Capibaribe e Toritama, entre os anos de 2015 e $2019^{5}$. Nesse período, foram realizadas trinta e nove entrevistas com homens e mulheres trabalhadores(as) na confecção, sendo, na sua maioria, costureiras ${ }^{6}$ proprietárias de facções domiciliares que normalmente se localizam na sala, quarto ou garagem de suas residências. $\mathrm{Na}$ cidade de Jardim de Piranhas, o trabalho de campo envolveu duas visitas ocorridas em janeiro e março de 2019. Conhecemos pequenas e médias tecelagens e realizamos oito entrevistas, sendo cinco com mulheres e três com homens. Este artigo encontra-se estruturado da seguinte forma: primeiramente, apresentamos uma revisão das teorias que discutem a divisão sexual do trabalho, evidenciando a atualidade do pensamento de Heleieth Saffioti e, em seguida, apresentamos as experiências empíricas do trabalho das mulheres costureiras e faccio-

${ }^{4}$ Segundo Rodgers (1989 apud Leite, 2009a, p. 74), “o conceito de precariedade envolve instabilidade, falta de proteção social e vulnerabilidade econômica ou social”.

${ }^{5}$ Os resultados desta pesquisa fazem parte do Projeto Trabalho e Globalização Periférica, financiado pelo CNPq. O número do processo é 402354/2016-8, sob a coordenação do Prof. Jacob Carlos Lima (UFSCar) e da pesquisa de doutorado desenvolvida no âmbito do Programa de Pós-Graduação em Ciências Sociais da Unicamp.

${ }^{6}$ As costureiras entrevistadas são faccionistas, ou seja, fazem algumas etapas do processo de fechamento de peças de vestuário, como fechar blusas, calças, camisetas, short, vestidos, entre outras peças, ou colocar golas e etiquetas, sendo a maioria das peças feitas com tecido de malha de algodão. 
nistas do Polo do Agreste Pernambucano e de tecelãs do município de Jardim de Piranhas, situado no sertão do Seridó, no Rio Grande do Norte, na região Nordeste do Brasil.

\section{DIVISÃO SEXUAL DO TRABALHO E DESIGUALDADES DE GÊNERO}

As teorias que discutem o conceito de gênero surgiram nos anos 1970, em um momento marcado por grande debate epistemológico entre os estudiosos das Ciências Sociais. A oposição entre masculino e feminino, a questão feminina e a formação da identidade sexual subjetiva foram adotadas como eixos centrais de diferentes teorias. Assim, a discussão sobre gênero faz parte das inúmeras tentativas desenvolvidas pelas feministas contemporâneas para explicar as desigualdades existentes entre homens e mulheres. No centro desse debate, estava uma crítica às bases naturalistas e universalizantes, comum às Ciências Sociais na época. Conforme Piscitelli (2009), as pensadoras pretendiam desmontar o "duplo procedimento de naturalização" que tornavam inatas as diferenças entre homens e mulheres, derivando daí as desigualdades de gênero.

Essa crítica endereçava-se às interpretações liberais que atestavam uma "disposição feminina” para o mundo doméstico, advogando uma separação "natural” entre as esferas ปิ públicas e privadas da vida social, mas, também, a algumas interpretações marxistas que identificavam, no surgimento do modo de produção capitalista (assentado na propriedade จิ privada, na família, na exploração da força de $\therefore$ trabalho pela burguesia), as bases da iniquidaळ de entre homens e mulheres. Se a visão liberal cindia as esferas do doméstico e do mundo público, sugerindo que uma não possuía relação com a outra, a contribuição marxista afirmava a existência de uma articulação entre opressão e exploração funcional para a reprodução da sociedade de classes.
Há um conjunto de polêmicas ${ }^{7}$ sobre as primeiras formulações marxistas desse problema. Os desacordos vão desde a centralidade do econômico na definição do modo de produção (deixando invisível a dimensão da reprodução), até a acusação de que há uma supremacia da classe social em detrimento das dimensões de gênero, raça, entre outras (Bezerra, 2020). No entanto, existe um reconhecimento de que o marxismo teve o grande mérito de afirmar um pressuposto fundamental: o de que "a opressão das mulheres não é uma invariante na história, mas sim produto de formações sociais; as relações entre os sexos não são naturais mas sociais" (Vinteuil, 1989, p. 8). Esse é um ponto de partida fundamental para a renovação epistemológica das Ciências Sociais, não apenas no que se refere à categoria gênero, mas aos avanços no debate do próprio conceito de trabalho e suas implicações na teoria feminista.

Nesse sentido, a ampliação do conceito de trabalho e a reformulação da divisão sexual do trabalho sob uma perspectiva feminista configuram uma importante contribuição a partir de uma leitura materialista da opressão das mulheres. Para as autoras materialistas francesas ${ }^{8}$, as relações sociais de sexo são constituídas de uma base material (trabalho) e de uma base ideativa (subjetividade, ideologia). Sendo atravessadas por antagonismos que localizam homens e mulheres em distintas posições de poder: "essas relações sociais se baseiam antes de tudo numa relação hierárquica entre os sexos, trata-se de uma relação de poder, de dominação" (Kergoat, 2009, p. 71).

Essas concepções objetivaram desnaturalizar as construções que se baseiam na diferenciação das desigualdades, sem abandonar a dimensão concreta das relações sociais, além de manter uma visão crítica da assertiva de que as relações de classes se inscrevem na instância econômica e as relações de poder se

${ }^{7}$ Ver mais em Hartmann (1979); Nicholson (1987); Saffioti, (1992, 2018); Vinteuil (1989), Piscitelli (2009).

${ }^{8}$ Referimo-nos às materialistas francesas, em especial, Danièle Kergoat e Helena Hirata. 
inscrevem na dimensão ideológica e simbólica (Kergoat, 2010). É a partir da compreensão da indissociabilidade entre a exploração por meio do trabalho assalariado e a opressão do masculino sobre o feminino que foi possível a ampliação da noção de trabalho:

É essa passagem do primado do econômico e das relações de exploração para a afirmativa de uma ligação indissociável entre opressão sexual (e de classe) e exploração econômica (e de sexo) que permite, a meu ver, reconceitualizar o trabalho, dinamizá-lo a partir da introdução de uma subjetividade efetiva, ao mesmo tempo "sexuada" e "de classe” (Hirata, 2002, p. 277).

Essa ampliação permitiu considerá-lo como trabalho assalariado ou profissional, e trabalho enquanto produção de vivência (Kergoat, 2002). Também possibilitou a visibilidade de outros tipos de trabalhos, como o doméstico, o trabalho não remunerado, o trabalho informal, até então ocultados pelas leituras economicistas. A divisão sexual do trabalho é, portanto, um elemento fundamental que organiza as relações sociais de gênero e o sistema de produção de mercadorias. E o antagonismo entre os grupos sexuados se dá no conflito cujo centro é a questão do trabalho e sua divisão. De acordo com Danièle Kergoat (2002; 2009), a divisão sexual do trabalho é a forma de divisão decorrente das relações sociais de sexo, e tem como características dois princípios norteadores: o da separação e o da hierarquia. O princípio da separação explica a existência de trabalhos de homens e de mulheres. Tal separação imputa aos homens o trabalho produtivo (com consequente dispensa do trabalho doméstico) e atribui o trabalho doméstico às mulheres (Hirata; Kergoat, 2003).

Já o princípio da hierarquia conceitua que o trabalho produtivo (por excelência realizado pelos homens) possui maior valor social do que o trabalho doméstico, que é relegado ao status de um "não trabalho": O "valor" do trabalho (não entendido como meramente econômico) é um problema que atravessa as relações sociais de sexo, pois induz a uma hierarquia, e hierarquia é relação social. Ainda de acordo com Kergoat e Hirata (2003), é dessa maneira que mulheres e homens são socializados na estrutura familiar e nas outras instituições, como Igreja e Escola, e que se constrói o lugar de desigualdade no qual as mulheres se inserem no mercado de trabalho (Bezerra, 2018).

Souza-Lobo salienta que a divisão sexual do trabalho ${ }^{9}$ é uma construção social e histórica, ou seja, "se é certo que o capitalismo utiliza uma estratégia de 'dividir para reinar', a configuração dessas divisões é construída socialmente através das relações de classe, de raça, de gênero e das práticas sociais” (Souza-Lobo, 1991, p.170). Sabemos que, para Marx, as relações sociais de produção e reprodução social são determinadas pelo modo de produção dominante, contudo, para Souza-Lobo (1991), as diferenças entre homens e trabalhadoras não são somente um reflexo das relações econômicas, mas "são também relações de poder, regidas por leis e normas, tradições e hábitos" (ibidem, p. 171).

Dentro desse debate, surge o conceito de gênero enquanto categoria analítica para tratar dessa construção desigual das relações entre homens e mulheres. Proposto, inicialmente, pela historiadora Joan Scott (1995), a definição de gênero recebeu contribuições de muitas teóricas e possibilitou uma renovação na teoria crítica feminista. Conforme definido por Scott, o gênero é um elemento constitutivo das relações sociais baseado nas diferenças percebidas entre os sexos, e é uma forma primeira de significar as relações de poder (Scott, 1995)..$^{10}$ Como elemento constitutivo das relações sociais baseadas nas diferenças entre os sexos, ela considera quatro dimensões fundamentais: a simbólica, a organizacional, a normativa e a subjetiva.

9 "A divisão sexual do trabalho produz e reproduz a assimetria entre práticas femininas e masculinas, constrói e reconstrói mecanismos de sujeição e disciplinamento das mulheres, produz e reproduz a subordinação de gênero dominação" (Souza-Lobo, 1991, p.171).

${ }^{10}$ Para Scott (1995), as mudanças na organização das relações sociais correspondem sempre a mudanças nas representações de poder, mas a direção da mudança não segue necessariamente um sentido único. 
Como teórica feminista e marxista, Heleieth Saffioti (1992) incorporou o conceito de gênero como categoria fundamental para as suas reflexões. Bezerra (2018), analisando as contribuições de Saffioti, destaca que não existe para a autora uma sexualidade biológica independente do social. Assim, sem se distanciar da formulação de Scott, ela compreende o gênero como uma "elaboração social do sexo" (Saffioti, 2004). Para Saffioti, "gênero" não implica necessariamente desigualdade e nem aponta o vetor de dominação, por isso,

na direção de situar que gênero se inscreve numa relação de dominação e exploração capitalista, Saffioti aponta que as classes sociais são desde sua gênese um "fenômeno gendrado" e que, por sua vez, a emergência do capitalismo introduziu transformações nas relações de gênero (anteriores à sociedade de classe) (Saffioti, 2004, apud Bezerra, 2018, p. 34-35).

A dominação tem, para Saffioti, uma centralidade na compreensão da imbricação entre as relações sociais de gênero e a exploração capitalista. Nesse âmbito, o patriarcado é, justamente, o conceito que marca e historiciza essa relação de poder, uma vez que, para a autora, o gênero é muito mais amplo que patriarcado, porque neste "as relações são hierarquizadas entre seres socialmente desiguais, enquanto o gênero compreende também relações igualitárias" (Saffioti, 2004, p. 119). Em outras palavras, patriarcado é um caso específico das relações de gênero e sua constituição se dá no âmbito das relações de produção e na esfera pública (é uma relação civil). O patriarcado não se configura como um sistema à parte do capitalismo, mas é um regime de dominação-exploração, intrinsecamente articulado com o capitalismo, os quais se fundiram historicamente numa simbiose patriarcado-racismo-capitalismo, não sendo autônomos, muito menos interconexos, mas fazem parte do mesmo sistema.

Essa base teórica permite articular uma perspectiva de gênero, enovelada às classes sociais e ao racismo, e encontra no patriarcado e na divisão sexual do trabalho elementos que não apenas explicam a permanência dos pa- drões discriminatórios na sociedade capitalista, mas os historicizam, abrindo a possibilidade de interrogar sobre as tendências de mudanças e transformações nesses padrões, as quais nos servem de referencial para refletir sobre a atualidade da inserção das mulheres no trabalho assalariado ou autônomo, especialmente no contexto do desenvolvimento da indústria têxtil e de confecções, conforme é o objetivo deste artigo. Assim, a predominância das mulheres nas ocupações ligadas a esta indústria é um tema que vem sendo tratado desde os primeiros estudos que inauguraram um campo do pensamento feminista. A própria Heleieth Saffioti é uma das autoras que observou no livro "Do Artesanal ao Industrial: a exploração da mulher. Um estudo de operárias têxteis e de confecções no Brasil e nos Estados Unidos" (1981), a desigualdade presente na inserção das trabalhadoras têxteis no mercado de trabalho assalariado, e apontou para uma tendência de precariedade associada à questão de gênero. O bias de gênero, conforme tematizaram Araújo e Amorim (2002), segue sendo a tônica que organiza os territórios produtivos no ramo de confecções, e é sobre essa dimensão que trataremos nas seções a seguir.

\section{O POLO DE CONFECÇÕES DO AGRESTE PERNAMBUCANO}

O Polo de Confecções do Agreste Pernambucano tem sua origem datada por volta dos anos 1940-1950. Os principais municípios que o representam são Santa Cruz do Capibaribe, Toritama e Caruaru, mas atualmente abrange outras cidades da região e também áreas rurais, dentro e fora deste estado. Surgiu a partir das necessidades de sobrevivência da população local que se mantinha por meio de atividades relacionadas à pequena produção agrícola, voltadas para o autoconsumo e para o cultivo do algodão, o qual era denominado de "ouro branco". Essas atividades entraram em declínio devido às secas que predominaram na região, 
bem como pelo alastramento da praga do bicudo, que tornou inviável a produção do algodão. De acordo com Bezerra,

a constituição do que conhecemos hoje como Polo de Confecções do Agreste de Pernambuco remonta a esse período de crise da cultura algodoeira que, associada à estiagem que assolava a região e às constantes perdas das culturas de subsistência (milho, feijão e mandioca), deixou milhares de famílias em situação de miséria, sem alternativas para sobreviver da agricultura e da pecuária (Bezerra, 2018, p. 86).

Tal situação levou grande parte da população rural a buscar alternativas econômicas nas áreas urbanas e a desenvolver o comércio e as feiras populares. Conforme relatam os moradores locais, a partir daí teve início a Feira da Sulanca, ${ }^{11}$ no município de Santa Cruz do Capibaribe. Até o final da década de 1940 e início de 1950, a atividade de confecção envolvia basicamente o trabalho artesanal realizado com retalhos de tecidos adquiridos das sobras da produção das indústrias têxteis de Recife. Assim, as mulheres que já tinham alguma experiência anterior com a costura iniciaram a produção de pequenas peças para vestir a própria família e depois começaram a investir na confecção de colchas de retalhos, que eram comercializadas nas calçadas da cidade. Segundo Milanês,

No início, o ofício da costura era exclusivamente feminino. Os homens eram responsáveis pela comercialização dos produtos. No entanto, com o passar do tempo os homens passaram a se inserir neste ramo de atividade, pois, para muitos o "mundo da sulanca" se estabelecia como uma grande oportunidade de trabalho (Milanês, 2015, p.35).

A partir dos anos de 1960, com o sucesso nas vendas, os "sulanqueiros"12 começam a buscar tecidos em São Paulo, na região do Brás,

${ }^{11}$ O termo "Sulanca" é resultado da soma das palavras sul com helanca, ou seja, eram retalhos do tecido chamado de helanca que eram trazidos pelos viajantes ao retornarem das viagens ao sul. Os mesmos eram utilizados pelas mulheres costureiras da região, para produção de peças com baixo valor agregado, que eram vendidas nas feiras locais.

${ }^{12}$ Segundo Milanês (2015), os sulanqueiros eram comerciantes que viajavam pela região para vender as confecções produzidas pelas costureiras, sendo que o pagamento era realizado no retorno da viagem. ocasião em que foi criado o termo Sulanca. Nos anos de 1980 e 1990, o sucesso da Feira da Sulanca em Santa Cruz já era tão grande que atingia " 28 ruas do centro da cidade, sendo composta por 8.000 bancos de madeira fixos, e 2.000 vendedores em lona, que expunham suas mercadorias no chão, além de um número não contabilizado de vendedores ambulantes" (Pereira Neto, 2013, p. 165). Segundo Veras de Oliveira (2013), nos anos 2000, a produção de confecções na região passou por importantes transformações e, entre elas, a principal foi a mudança do nome de "Feira da Sulanca" para "Polo de Confecções do Agreste de Pernambuco", como uma forma de incluí-lo no padrão mais geral de desenvolvimento da cadeia têxtil e de confecção. Hoje, o Polo do Agreste é o segundo maior do Brasil neste setor, ficando atrás apenas do Polo de São Paulo, e vem sendo analisado como modelo de empreendedorismo informal ${ }^{13}$.

Todo esse dinamismo da Feira da Sulanca foi possível graças ao trabalho de mulheres e homens, que foram criando pequenas fábricas e facções dentro do espaço domiciliar e, na maioria das vezes, envolvendo toda a família na produção. Assim, desde o início, o trabalho informal e domiciliar, baseado na amizade e na confiança, são suas características predominantes, que não desapareceram, mas vêm sendo analisadas com uma certa positividade. De acordo com Lima, Corteletti e Araújo (2018, p. 12), "a ideologia do empreendedorismo ressignificou a informalidade na produção como trabalho flexível. O que era visto como arcaico e atrasado tornou-se sinônimo de modernidade”. Segundo Pereira (2019), houve o fortalecimento da motivação para transformar o "empreendedorismo por necessidade" em "empreendedorismo por oportunidade" (Sebrae, 2017, apud Pereira, 2019, p. 156).

Além disso, a terceirização e a subcontratação também são estratégias de trabalho flexível, utilizadas como forma de diminuir os

${ }^{13}$ Ver mais em Veras de Oliveira (2013), Pereira Neto (2013), Burnett (2014), Freire (2016), Bezerra (2018), Lima, Corteletti e Araújo (2018), Pereira (2019). 
custos de produção não apenas das unidades produtivas informais, mas também das empresas formais. Essas formas de organização do trabalho se desenvolvem de modo articulado a um padrão de gênero que ora se apresenta na sua forma mais clássica, a partir de uma nítida divisão sexual do trabalho (a costura marcada como trabalho de mulher), ora aponta para possíveis transformações e deslocamentos nesse padrão. Um exemplo é a crescente presença dos homens em várias atividades dentro do Polo, inclusive, nas funções de costura, como identificamos na fala de um de nossos interlocutores: "hoje em dia é muito comum você encontrar em qualquer confecção homens costurando, mas na década de 50, 60, lá bem no início, a atividade de costura era uma atividade primeiramente feminina" (Secretário, entrevista concedida a Bezerra, 2018). Com o deslocamento da produção de confecções para áreas rurais temos, assim, uma experiência produtiva cuja constituição e conformação se dá imbricando intrinsecamente gênero e trabalho, opressão e exploração.

\section{TRABALHO E VIDA COTIDIANA DE MULHERES E HOMENS NA COSTURA}

Nesta sessão, vamos nos remeter a alguns aspectos das experiências cotidianas de จิ mulheres e homens trabalhadores do Polo de C. Confecções do Agreste, analisando variáveis ¿े como: entrada na atividade de costura, renda, dupla jornada de trabalho, divisão sexual จิ do trabalho na produção, espaço doméstico e $\dot{2}$ como percebem a entrada dos homens neste s setor de atividade. Salientamos que os nomes $\therefore$ das(os) entrevistadas(os) que aparecem no texto são fictícios, como forma de proteger suas verdadeiras identidades. E observamos que a maioria das costureiras entrevistadas aprendeu a atividade com familiares, dentro do espaço doméstico, em especial, com suas mães, avós e tias, como é o caso da costureira Tânia:
Eu sou natural do Brejo, mas me criei em Jataúba, num sitiozinho, aí comecei a costurar ainda quando criança, com a minha família todinha, com as minhas tias, minha mãe e minha irmã. Aí fui aprendendo a costurar lá no sítio, só que no sítio a gente tinha muita dificuldade, aí eu vim pra Santa Cruz (Tânia, 42 anos).

Esse, também, é o caso da Patrícia, que veio ainda na adolescência para Santa Cruz, e aprendeu a costurar com a patroa da sua mãe. Possivelmente, essa patroa tinha algum interesse na preparação dessa nova força de trabalho.

Eu vim para Santa Cruz com 12 anos, meus pais se divorciaram e a minha mãe veio tentar a vida aqui, ouvimos falar que aqui era bom de emprego, que era um lugar bom para empreender. Minha mãe pediu pra patroa dela ensinar a mim e ao meu irmão a costurar, aí comecei a costurar com 12 anos de idade. Comecei costurando biquíni e ganhava na época 25 reais por semana (Patrícia, 36 anos).

Vimos nos depoimentos que o início do trabalho ainda jovem (muitas vezes adolescente ou criança) é um traço que caracteriza o processo de socialização das meninas, explicitando os princípios normativos do gênero. No Polo do Agreste de Pernambuco, a costura era uma ocupação tipicamente feminina e constitui um dos elementos que explicam a atração de grandes contingentes de mulheres para a produção de roupas, e todas as entrevistadas eram de cidades circunvizinhas ou da área rural, apenas uma era de outro estado. Elas foram atraídas pela dinâmica de desenvolvimento, cada vez maior, das atividades de costura relacionadas à região, e pela necessidade de emprego e renda. Somada a essa mobilidade territorial, vimos, também, uma mobilidade de posição dentro do processo de produção e comercialização, sendo muito comum, por exemplo, casos de costureiras que trabalharam em empresas formais com carteira assinada e direitos sociais garantidos, e após o desligamento, optaram por colocar negócio próprio, em seus domicílios. De acordo com essas trabalhadoras, tal decisão deu-se porque é mais fácil para elas, gera mais liberdade e autono- 
mia, uma vez que conseguem combinar as atividades de costura com as atividades de cuidado, como a educação e alimentação dos filhos e demais familiares, bem como dos cuidados com a casa de maneira geral. Ou seja, permite que elas combinem as atividades produtivas com as reprodutivas e, com isso, acabam trabalhando longas e exaustivas jornadas de trabalho, como é o caso da rotina de Paula, que tem uma filha de 8 meses e um filho de 5 anos:

Na parte da manhã, ela (filha) dorme bastante e enquanto ela dorme eu costuro. Às vezes eu pego e coloco ela no bebê conforto, deixo no meu lado e fico costurando. O Henrique não me dá muito trabalho, fica brincando, mas eu tenho que parar a costura para ajudar ele a fazer as tarefas, depois paro para fazer o almoço e para dar a comida. Quando ela chora, também preciso parar de costurar. À noite, quando meu esposo está em casa, ele me ajuda, fica com ela e eu fico trabalhando até às 23 horas (Paula, 38 anos).

Essa rotina da trabalhadora, acima descrita, é bem conhecida entre as costureiras faccionistas. Normalmente elas começam a trabalhar por volta das 7 da manhã e vão até às 23 horas, ou seja, uma média que varia entre 12 e 16 horas diárias. A participação do marido nas atividades domésticas ocorre sempre como ajuda e não como divisão equilibrada dessas atividades. A ajuda por parte dos maridos é mais significativa no período da noite. No entanto, houve uma trabalhadora que afirmou que o esposo mais atrapalhava do que ajudava nas atividades domésticas diárias. Identificamos que as mulheres compreendem ter uma relativa autonomia em relação às decisões tomadas no ambiente doméstico, observando-se que os papeis de gênero permanecem inalterados, ou seja, a questão dos cuidados e das tarefas domésticas continua sendo naturalizada e aceita pelas trabalhadoras como sendo algo normal, pois, reproduzem uma situação já bem conhecida no ambiente em que foram criadas, conforme podemos verificar no depoimento da costureira Vanessa: "Meu marido me ajuda. Só pego uma pessoa uma vez por ano pra fazer uma geral, lavar teto, parede, etc. Já fiz muito isso, mas no momento meu problema de coluna não deixa, mas no mais eu mesma faço e a filha e o marido ajudam" (Vanessa, 49 anos).

Em relação à renda obtida com o trabalho há uma diversificação das situações. A média de ganho das costureiras entrevistadas que são terceirizadas varia entre $\mathrm{R} \$ 800$ e $\mathrm{R} \$ 3.000$ reais mensais, no entanto, as duas faccionistas que fazem sua própria modelagem, são donas da marca e possuem box no Moda Center, afirmaram que conseguem obter uma renda bem superior. Normalmente, o serviço é pago por produtividade, assim quanto mais peças costurarem, maiores serão os rendimentos. Isso, na visão delas, é um aspecto que diferencia o trabalho domiciliar informal do trabalho formal, uma vez que, trabalhando formalmente, receberiam um salário fixo e a produtividade é paga mensalmente, com o valor equivalente a um dia de trabalho, tendo como base de cálculo o salário mínimo. Sobre esse aspecto da renda, a costureira Amanda considera que os rendimentos são maiores no trabalho autônomo:

\footnotetext{
Vamos botar em média 50\% a mais. Até as meninas que trabalham comigo, que trabalham em casa como terceirizadas, estão preferindo trabalhar em casa do que trabalhar nas fábricas. A liberdade é bem maior porque se trabalha por produção, se Amanda trabalhar e fizer 100 peças ela vai receber por 100 peças e muitas vezes na fábrica a costureira faz 200 peças e não tem diferença no salário. Então, pra gente é bem melhor trabalhar em casa (Amanda, 48 anos).
}

Assim, a informalidade representa uma possibilidade de renda maior do que no trabalho formal. No entanto, as condições de trabalho no domicílio são até mais precárias, uma vez que trabalham em ambientes pequenos e fechados, com pouca ventilação, sem separação entre o espaço doméstico e o da produção, o que é perceptível pela presença de brinquedos dos filhos por cima das máquinas e misturados a uma grande quantidade de peças, de matérias primas, e aviamentos utilizados nas confecções. Vimos, inclusive, situações em que os filhos brincavam com as máquinas de costura, o que representa um perigo 
para as crianças. Frequentemente, as máquinas são antigas e quando não conseguem adquirir máquinas novas, costumam comprar máquinas usadas. Para algumas delas, a compra de máquinas novas foi possível devido ao valor recebido na rescisão contratual do trabalho em empresa anterior, mas vimos também casos nos quais as máquinas são de propriedade da contratante do trabalho, não sendo permitido que elas sejam utilizadas para outra contratante. Nessas situações, as costureiras se obrigam a trabalhar somente para a mesma contratante, o que acaba gerando uma dependência e ao mesmo tempo instabilidade financeira. Isto indica uma contradição no discurso sobre autonomia e liberdade no trabalho, pois, muitas vezes a contratante é vista pelas terceirizadas como "patroa", aquela que distribui serviços como: peças cortadas para serem fechadas, ou para colocar a gola, ou outra etapa da confecção. No nosso entender, a autonomia contrasta com uma forte dependência que é baseada na amizade e confiança, cujo rompimento significaria ir contra a moral e os costumes culturais locais.

Apesar disso, as entrevistadas avaliam muito bem o trabalho executado no domicílio, tanto em termos de rendimentos, quanto pela possibilidade de conciliação entre o trabalho produtivo e o reprodutivo. Ao avaliar a situação laboral atual, elas sempre comparam com experiências anteriores, as quais são sempre retratadas como bem mais degradantes, o ิㅗㅇ que lhes possibilitam avaliar com mais posi- tividade suas realidades atuais. Entretanto, จิ ceira. Preocupadas com essa questão da insta$\dot{2}$ bilidade, em alguns casos, elas incentivam e ळ consideram importante ter algum membro da

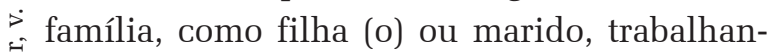
do em empresas formais do local, o que lhes proporciona uma maior segurança financeira, mesmo sendo baixa, mas sempre no mesmo dia do mês. Há também situações em que as costureiras trabalham durante o dia em uma empresa formal e à noite trabalham na facção domiciliar própria, onde contam com o apoio de outros membros da família.

Enfim, as situações encontradas entre as experiências analisadas são complexas e variadas, tendo em comum a luta pela própria sobrevivência e de suas famílias. Em alguns casos, quando existem muitas encomendas para dar conta do trabalho, elas subcontratam outras costureiras, as quais trabalham em seus próprios domicílios, formando uma espécie de cascata ou hierarquia da produção, estabelecida entre a proprietária da marca que faz a criação e modelagem, as costureiras terceirizadas e costureiras subcontratadas. Na realidade estudada, terceirização e subcontratação são estratégias necessárias para manter os negócios, uma vez que as costureiras possuem baixo capital de giro.

Apesar das mulheres serem o sujeito principal, cuja força de trabalho está presente em vários setores na rede produtiva do Polo, temos observado um aumento significativo da presença dos homens nas atividades de confecção na região ${ }^{14}$. Esse contexto traz novos elementos para a dinâmica das relações de gênero no ambiente de trabalho, especialmente, no espaço domiciliar. Para a maioria das entrevistadas, essa entrada dos homens deve-se tanto ao fato da ausência de ocupações em outros setores mais classicamente "masculinos", como ao fato da remuneração na costura ser superior ao ganho em outras atividades, bem como, ao desemprego. "As mulheres ganhavam bem, começaram a ficar bem sucedida, e não tinha emprego pra eles" (Dona Luz, 56 anos). Para alguns homens, o declínio da atividade agrícola e o desenvolvimento da produção de roupas na região os atraíram para o setor:

Aqui no Nordeste antigamente era mais agricultura e hoje não tem mais tanta chuva como antes. Aí começou a aparecer confecção, a feira da Sulanca, e muita gente não tinha como sobreviver da agricultura e passaram para o ramo da confecção. Aí começou os homens trabalhar mais em costura, mais na lavanderia (Cadú, 29 anos).

${ }^{14}$ Ver mais em Bezerra (2018). 
O manuseio da máquina de costura passou a ser uma prática corriqueira para os homens, o que provocou certa naturalização da sua presença na trama produtiva regional, expressando, inclusive, uma masculinização de alguns espaços. É o caso do trabalho no interior, das lavanderias de jeans ${ }^{15}$ e de algumas funções nas empresas e facções de confecção. No entanto, há uma reedição da distinção entre o que é "trabalho de homem" e "trabalho de mulher". Esse entendimento passa pela forma como a mão de obra é distribuída na organização do processo produtivo e pela maneira como age a divisão sexual do trabalho. A entrada dos homens não ocorre indistintamente e não se distribuem equitativamente ao longo da produção. O que há, na verdade, é uma inserção diferenciada dessa força de trabalho, através da distinção dos setores onde estão as forças de trabalho de homens e mulheres, e de uma separação entre as máquinas operadas por estas e por eles ${ }^{16}$. Essa separação não é justificada pela estandardização da produção na qual os homens foram deslocados para as máquinas tecnologicamente mais avançadas, mas pelo tipo de habilidade e dispêndio de força necessária à realização do trabalho. Também, oculta atributos tidos como "naturais" de um e de outro sexo: "as mulheres aparecem como portadoras de um tipo de motricidade fina nata, qualidade necessária para a costura na máquina reta que, por sua vez, não é encontrada nos homens" (Bezerra, 2019, p. 15). As máquinas que são consideradas "pesadas" e de costura mais rápidas são normatizadas como masculinas, ao passo que aquelas que requerem acuidade visual e um cuidado maior no acabamento da costura, cristaliza-se como um equipamento de mulher ${ }^{17}$.

${ }^{15}$ As lavanderias de jeans são empreendimentos que executam os serviços de lavagem, amaciagem, tingimento e alguns acabamentos como puídos e envelhecimento. Ver mais em Pereira (2018).

${ }^{16}$ Nas confecções, cabe às mulheres, fundamentalmente, o manuseio da máquina reta e da overloque, enquanto os homens ocupam as máquinas de travetar, máquinas de pressão que servem para pregar botões e a máquina de braço (Bezerra, 2019, p. 15).

${ }^{17}$ Identificamos que há uma recusa explícita dos homens em manusear a máquina reta.
Assim, como é uma realidade para a maioria das mulheres, a possibilidade de conciliar o trabalho profissional com outra atividade remunerada no domicílio fortalece esse movimento dos homens em direção ao trabalho da costura. De maneira geral, a presença dos homens em espaços considerados femininos é encarada com tranquilidade pelas mulheres, que relatam não encontrarem grandes problemas. Pelo contrário, argumentam que a presença deles desobriga as mesmas de terem que fazer os trabalhos mais "pesados". No entanto, embora essa entrada dos homens se dê a partir de questões que não conflitam (aparentemente) com as relações de gênero, identificamos que a divisão sexual do trabalho e o lugar privilegiado que o patriarcado confere aos homens diferencia desigualmente essa inserção.

Conforme Bezerra (2018), os homens são considerados mais ágeis e dão uma produtividade maior que as mulheres no interior das fábricas e facções. No entanto, as entrevistadas reconhecem que essa desenvoltura masculina na produção de roupas se dá porque sobre eles não pesa o acúmulo da jornada de trabalho produtiva e doméstica: "Eu acredito que homem é mais descansado que a mulher. Quando ele chega em casa ele não tem tanta tarefa como a mulher. Chega em casa, tomou banho, jantou, vai descansar. A mulher não. Ele tem um pouco mais de disposição no outro dia pra trabalhar" (Neta, 38 anos). Assim, independente de as pessoas com quem compartilham a moradia desenvolverem ou não atividade remunerada, dentro ou fora de casa, os homens entrevistados não realizam o trabalho doméstico como centralidade, como vimos na fala de Nero: "Se tiver um copo sujo e tiver um pires, eu tomo água no pires e não lavo um copo, espero ela lavar!" (Nero, 47 anos). A única condição em que alguns desses trabalhadores colocam-se para realizar alguma tarefa doméstica é em casos de adoecimento da esposa.

Essa é uma questão importante para pensar o comportamento das relações de gênero no interior das atividades que conformam 
o Polo do Agreste. Primeiro, porque, como já relatado, a remuneração é calculada por peças e a questão da produtividade ${ }^{18}$ influencia para que os trabalhadores e trabalhadoras tenham um maior rendimento. Assim, as mulheres acabam, ao final, recebendo uma remuneração menor do que seus colegas homens. Outra questão associada a esta, é a continuidade do "lugar de mulher", ou obrigação feminina, a realização, se não de todas, mas da maioria das atividades ligadas ao universo doméstico. Isso demonstra o quão ainda é central a divisão sexual do trabalho nos termos formulados por Danièle Kergoat (2002), de uma separação entre "trabalho de mulher" $\mathrm{x}$ "trabalho de homem”, relegando as atividades domésticas às mulheres, e desvalorizando-as.

Na nossa compreensão, o Polo de Confecções de Pernambuco só consegue manter seu desenvolvimento porque se beneficia desse padrão de desigualdade de gênero e opressão patriarcal, articulando-o com a precariedade do exercício laboral para o conjunto dos seus trabalhadores. Manter um trabalho não remunerado, realizado pelas mulheres nos interiores dos lares, é fundamental para o rebaixamento dos salários e para a não disponibilização de serviços básicos de socialização do trabalho doméstico e de cuidados. Esse padrão discriminatório e clássico das relações entre homens e mulheres organiza toda a trajetória do Polo, acompanhando suas transformações e colaborando para a atualidaจิ de. Como exemplo, os homens também entram ¿. no trabalho na confecção com a perspectiva de colocar um negócio próprio e ter sua empresa fa\% miliar, no entanto, percebemos algumas nuances จิ nos motivos que levam um e outro a esse desejo. $\dot{\sim}$ Enquanto para as mulheres é muito forte a quesले tão de querer ter o próprio negócio para facilitar gerenciar e organizar melhor o espaço doméstico e o cuidado com os filhos, há, para eles, a perspectiva de "ser o próprio patrão", subtendendo,

${ }^{18}$ Mesmo os trabalhadores e trabalhadoras formalizados não estão imunes a essa questão, uma vez que as empresas mantêm uma prática de burlar a legalidade com mecanismos de "bônus" ou "gratificação" para obrigar os empregados a aumentarem a produção. inclusive, a questão de gerir a força de trabalho de outras pessoas.

Em relação à questão da formalidade e da informalidade, percebemos um movimento de saída das mulheres do trabalho formal para costurar informalmente, já os homens estão mais preocupados com a estabilidade que o emprego de carteira assinada proporciona, sendo um dos principais atrativos da mão de obra masculina para as empresas de confecção. Vale salientar que as dificuldades vivenciadas pelas trabalhadoras são antigas, estão relacionadas à origem das desigualdades de gênero e encontram-se diretamente relacionadas à divisão sexual do trabalho. Para Nogueira (2006), falar sobre a presença das diferenças entre homem e mulher significa refletir sobre as especificidades de gênero existentes na sociedade capitalista e que são utilizadas para controlar a hierarquia com vistas à reprodução e acumulação do capital. Assim, para a autora "a desigualdade na divisão sexual do trabalho nas esferas produtiva e reprodutiva é central para as relações de poder, principalmente, o poder exercido pelos homens sobre as trabalhadoras, presente na estrutura da família patriarcal” (Nogueira, 2006, p. 28).

\section{ENTRE FIOS, MÁQUINAS E TE- CIDOS: as mulheres na produção têxtil de Jardim de Piranhas- RN}

A arte de transformar fios em tecido e o manejo com a máquina de costura foi considerada, historicamente, um trabalho feminino. Saffioti (1981) nos lembra que, no Censo de 1920, no Brasil, as mulheres representavam $65,1 \%$ da mão de obra existente na indústria têxtil e 69,7\% no setor de confecções. Esse percentual vai sendo reduzido ao passo que esses setores vão incorporando inovações tecnológicas e as mulheres passam a ocupar posições menos privilegiadas, que a autora chama de baixo terciário, ou em ocupações realizadas em domicílio, na maioria dos casos, excluídas 
de benefícios sociais. O município de Jardim de Piranhas, situado no sertão do Seridó, no estado do Rio Grande do Norte, é especializado na produção de redes, cobertores, toalhas e panos de prato, e se constitui como a principal atividade econômica, geradora de trabalho e renda desta localidade.

A "cidade dos teares" apresenta uma população de 20 mil habitantes, distante 315 km da capital Natal, e 32 km de Caicó, principal centro comercial da região do Seridó. Juntamente com São Bento e Brejo do Cruz, municípios paraibanos, distantes 30 e $17 \mathrm{Km}$ respectivamente de Jardim de Piranhas, fazem parte de um circuito de produção e comércio têxtil (Araújo; Oliveira, 2020). Essa produção não tem uma história recente. De acordo com registros de moradores da cidade, desde a década de cinquenta do século XX, já se produzia redes para dormir, de forma artesanal, nos chamados teares de madeira. Inicialmente se constituía como unidades de produção doméstica guardando, ainda hoje, uma característica predominantemente familiar, apesar do crescimento e das mudanças ocorridas no processo produtivo do lugar nas últimas décadas. Mesmo congregando empresas formais de pequeno e médio porte, a informalidade é uma característica marcante neste Polo, apresentando alto nível de trabalho subcontratado e terceirizado, e baixo nível de assalariamento.

As mulheres sempre tiveram papel importante na indústria têxtil da cidade de Jardim de Piranhas, desde os tempos iniciais, quando a produção ainda era focada nas redes de dormir. Embora, com inserção em atividades subcontratadas, consideradas com baixo valor social e baixa remuneração, a presença delas fazia parte das cenas urbanas presenciadas nas calçadas, salas ou quintais, onde se poderia vê-las com peças estendidas, fazendo os acabamentos manuais chamados de "mamucaba"19.

${ }_{19}$ Mamucaba é um termo usado para definir uma atividade de acabamento que consiste em arrematar o tecido da rede nos extremos do comprimento, costurando na base da trança. Essa tarefa era realizada manualmente, quase exclusivamente por mulheres, mas hoje é realizada por máquinas. (Araújo; Oliveira, 2020).
Era uma atividade que começava cedo para as meninas do lugar, que aprendiam com as mães essa habilidade tida como naturalmente feminina, legitimada pela condição de gênero.

A produção desenvolvida em Jardim de Piranhas, envolvendo os artigos de cama, mesa e banho, exige uma fase de acabamento que é realizada manualmente nas residências, de forma subcontratada ou terceirizada, o que torna a informalidade e precariedade uma marca do Polo. As mulheres são as principais responsáveis pela prestação desses serviços, o trabalho realizado em casa favorece a conciliação com os trabalhos domésticos, atribuições vistas ainda nos dias atuais, como responsabilidade feminina. As atividades de acabamento, exigidas nas peças, como costura e estamparia, envolvem saberes historicamente reconhecidos como pertencentes às mulheres. Esse efeito de gênero é naturalizado a partir de noções de masculinidades e feminilidades, constituindo-se enquanto práticas regulatórias (Butler, 2010).

A participação das mulheres no mundo da produção torna-se cada vez mais significativa e uma série de fatores tem contribuído para essa inserção. A redução na taxa de fecundidade, o aumento do nível de escolaridade, o aumento das famílias monoparentais femininas e as mudanças sociais e culturais que envolvem as relações de gênero provocaram mudanças de concepções em relação à dependência feminina e sua posição dentro das esferas produtiva e reprodutiva. No entanto, esses avanços apresentam uma série de ambiguidades. Para Biroli (2018) a dualidade entre o público e o privado reproduz hierarquias de gênero, embora de formas diferenciadas, daí a importância de atentarmos a esses efeitos, considerando a intersecção de determinados marcadores sociais, tais como gênero, raça/etnia, classe e sexualidade, para uma compreensão mais alargada da divisão sexual do trabalho e dos deslocamentos que vêm ocorrendo, principalmente, nos contextos em que prevalece a informalidade como elemento da precarização das condições de trabalho. 
Nas últimas décadas, este Polo tem vivenciado mudanças significativas, seja com a entrada de equipamentos mais modernos, substituindo os teares manuais de madeira por máquinas mecanizadas, seja na diversificação de produtos. Hoje não se produz apenas redes, ao contrário, a produção desse artigo é ínfima em comparação aos artigos de cama, mesa e banho. Os panos de prato se tornaram o produto de maior destaque em Jardim de Piranhas, que se tornou um dos maiores produtores do país (Santos, 2015). Destaca-se uma questão observada no estudo que realizamos, as mulheres têm assumido novas posições, acompanhando as mudanças que ocorreram e vem ocorrendo nessa realidade produtiva, configurando-se como um protagonismo feminino.

Uma característica marcante na cidade é a produção familiar, o que justifica, em certa medida, o envolvimento de famílias inteiras, por várias gerações, nesse setor. A introdução no mundo da produção acontece por meio de conhecimentos tácitos, passados através das relações familiares. Quando perguntamos como uma entrevistada tinha entrado no ramo, ela respondeu: "Nasci dentro de tear". É como se fosse um destino certo. Há uma ligação entre o espaço e o modo de vida das pessoas do lugar, um vínculo entre o espaço social e o pertencimento da comunidade envolvida na produção. Saberes e fazeres engendram uma prática social no enlace entre lugar e prática ชิ produtiva. Desde a década de 90, com a escas- sez na venda de redes, os produtores começaram a diversificar cada vez mais a produção \& e os panos de prato passaram a ser o produto จิ mais produzido em Jardim de Piranhas.

O que se explica, por um lado, pelos baixos custos da confecção, garantindo que qualquer pessoa pudesse produzir essa mercadoria sem grandes investimentos. Por outro, a forte aceitação no mercado regional e nacional elevou a demanda por panos de pratos e levou, consequentemente, a envolver um número ainda maior de interessados e proprietários de unidades têxteis (Araujo; Oliveira, 2020, p. 112).
A ascensão desta mercadoria levou aos deslocamentos da posição que as mulheres ocupavam nesse Polo têxtil. Um produto tão ligado ao mundo doméstico, tido como espaço por excelência de domínio das mulheres, é a porta de entrada para o mundo dos negócios e para o espaço público. A presença das mulheres pôde ser notada ao longo do tempo e acompanha as mudanças que esse setor produtivo atravessou nas últimas décadas. Essa questão nos instiga a realizar as seguintes indagações: qual o lugar que a mulher ocupa, no município, no contexto atual? Considerando que essa produção exige uma parte significativa de acabamentos e essas atividades são realizadas por mulheres, demarcando os espaços ocupados por homens e mulheres, como se expressa a divisão sexual do trabalho e de que forma novas posições assumidas pelas mulheres na cidade borram essa demarcação?

\section{DO MUNDO DOMÉSTICO PARA O MUNDO DOS NEGÓCIOS: desloca- mentos e permanências}

Em uma sociedade globalmente dominada pelo poder masculino, as mulheres exerceram entretanto todo o poder possível não foram somente vítimas ou sujeitos passivos. Utilizando os espaços e as tarefas que lhes eram deixados ou confiados, elas elaboraram, às vezes, contrapoderes que podiam subverter os papeis aparentes (Perrot, 2005, p.273).

A citação de Perrot é significativa para pensarmos a posição que as mulheres ocupam na produção têxtil de Jardim de Piranhas e como estas abriram brechas no mundo dos negócios, ainda tão dominado pelos homens e por uma cultura patriarcal. Para Hirata e Kergoat (2007), a divisão sexual do trabalho envolve a inserção de homens e mulheres de forma diferencial, considerando ofícios e profissões, e variando no tempo e no espaço, como também, a desigual divisão entre os sexos, do trabalho doméstico. Assim, pensar em divisão sexual do trabalho é, segundo Hirata (2002), atentar para a sua imbricação com as 
relações sociais entre homens e mulheres, que são relações desiguais, hierarquizadas, assimétricas e antagônicas. A divisão sexual do trabalho é assim, indissociável das relações sociais entre homens e mulheres, que são relações de exploração e de opressão entre duas categorias de sexo socialmente construídas (Hirata, 2002, p. 280-281).

O processo produtivo desenvolvido no lugar pesquisado envolve as etapas de urdição, tecelagem, corte, costura, estamparia (desenho e serigrafia) e embalagem. No caso dos panos de prato, estes também passam pelo alvejamento. Pudemos perceber uma divisão sexual do trabalho bastante demarcada, cabendo aos homens o trabalho de urdição, tecelagem e alvejamento, e, às mulheres, a costura, corte e outros acabamentos, como desenho, estamparia e embalagem. Se era comum a presença das mulheres comandando as máquinas de tear na sua forma artesanal, com a modernização destas, essa atividade produtiva torna-se eminentemente masculina, embora, algumas mulheres tenham relatado que sabiam tecer, e não exerciam a atividade porque já fazia parte da cultura local as mulheres não o fazerem, além dos argumentos da necessidade da troca de peças pesadas durante a produção. Assim, a divisão social no trabalho têxtil acaba reproduzindo concepções de gênero historicamente determinadas, com funções diferenciadas para mulheres e homens.

A presença masculina na costura não é muito comum no município pesquisado, embora o dono de uma tecelagem relate que gostaria de ter mais homens nessa atividade, pois assim evitaria que as mulheres ficassem conversando por muito tempo e isso interferisse na produção. O dono diz ainda que os poucos homens que trabalham na costura, quando assumem essa função, trabalham em casa, nas tecelagens fica mais difícil encontrá-los. Segundo o entrevistado,

É que o pessoal é meio machista. Eu doido para pegar um costureiro homem e botar no meio dessas mulheres, mas é porque é a cultura daqui (Pedro, 27 anos).
Eu tenho duas ali, aquela da ponta ela costura, não cala a boca e costura ligeiro. Se sentar uma do lado dela que não sabe costurar, conversando, aí a produção não vai no final do dia (Pedro, 27 anos).

Isto acaba reforçando estereótipos em torno do comportamento e sociabilidade das mulheres, vistas como propensas às conversas informais e fofocas, atitudes reprovadas no mundo do trabalho. Com as mudanças na produção, as mulheres passam a montar o próprio negócio com mais frequência. Começam a produzir e comercializar, tornam-se donas de teares, uma prática que vem se tornando cada vez mais recorrente na cidade, e, dessa forma, rompem com significados legitimados por representações de gênero que as colocam em posições inferiorizadas no mundo da produção, principalmente nos aspectos envolvendo poder de decisão e autonomia. De acordo com as histórias relatadas, muitas começaram a produzir de forma tímida, ainda tuteladas pelos pais, irmãos, ou companheiros, depois adquiriram autonomia e passaram a administrar o próprio negócio e ressignificaram a posição até então ocupada na produção têxtil da cidade. O reconhecimento vem das próprias mulheres do lugar. Uma entrevistada fala que o envolvimento das mulheres é muito significativo, revela força e coragem.

As mulheres daqui são muito ativas, trabalhadoras. Você vê muitas mulheres empreendedoras aqui. A quantidade de mulheres que são donas de tear aqui é muito grande! (Carla, 32 anos)

O caso de Marinete é bastante ilustrativo. Ela ficou viúva e hoje é uma empresária reconhecida na cidade. Conta como tudo começou. Diz que nada foi fácil e que a necessidade de sobrevivência a fez investir no próprio negócio. Conta que o segredo é que ela conhece bem o produto e investe na qualidade, além da criatividade para enfrentar as adversidades:

Todo mundo foi tendo aquela criatividade, começando no fundo de quintal, quase tudo começou no fundo de quintal, depois fazia aquele galpãozinho atrás da casa. Pro acabamento, não escolhia canto, 
era sala, era cozinha é onde desse para se acomodar para trabalhar (Marinete, 62 anos).

As experiências vivenciadas por Silvia e Lucia são bem semelhantes e revelam uma realidade bastante comum na cidade, ambas entraram em contato com o trabalho têxtil desde a infância e aprenderam a lidar com esse mundo produtivo, o que lhes asseguraram acreditar que podiam montar o próprio negócio. Silvia nasceu numa família de produtores têxteis e se envolveu nesse meio muito cedo. Quando casou, o marido também era do ramo. Decidiu que queria ter o seu próprio tear. Comenta que começou com quatro teares, hoje já está com 50. Diz que toma todas as decisões do seu negócio. Enquanto Lúcia nos lembra que aos 12 anos já trabalhava fazendo "mamucaba" em redes, depois passou para a estamparia. Quando casou, passou a ajudar o marido, que também era do ramo, até montar o seu próprio negócio. Fala das estratégias de criatividade em tempos de crise. Muitas mulheres que já tinham seus teares passam a produzir de forma terceirizada para contratantes do local. Como são peças que envolvem muito acabamento, elas usam a criatividade nos detalhes para diferenciar o produto e enfrentar a concorrência, e passam a produzir de forma bastante diversificada.

O fato de terem entrado no mundo dos negócios e comandar seus próprios teares não exime essas mulheres da responsabilidade dos trabalhos domésticos. A participação dos companheiros é vista, no máximo, como ajuda, ¿े principalmente nas atividades envolvendo o cuidado com os filhos.

Tem uma menina que mora comigo que me ajuda, quando ela não vem é comigo mesmo! Mas ele me ajuda nas coisas. Depois de pedir muito e brigar muito aí ele faz. Mais eu sempre faço as coisas em casa, eu acho que eu faço mais do que ela (Lúcia, 37 anos).

De acordo com as entrevistadas, cria-se uma tensão, no cumprimento de responsabilidades, entre vida profissional e vida familiar, obrigando-as a criarem estratégias para lidarem com essa situação. As estratégias passam desde criar recursos, tais como a determinação de tempo para conciliar as duas atividades, à delegar para outras mulheres as tarefas domésticas e familiares. No entanto, isso não as libera desse trabalho, pois "a gestão do conjunto do trabalho delegado é sempre de competência daquelas que delegam" (Hirata; Kergoat, 2007, p. 607). Quando falamos do protagonismo feminino na produção têxtil de Jardim de Piranhas, de forma alguma significa uma situação confortável para as mulheres, ao contrário, a característica histórica da indústria têxtil e de confecções, marcada pela produção familiar e artesanal, pautada na informalidade, reflete a realidade do setor têxtil de Jardim de Piranhas. Se até a década de 1980 a informalidade era percebida como algo transitório e a formalidade seria a meta a ser alcançada, no contexto atual, sob a égide do trabalho flexível, a informalidade adquire outra feição, assumindo uma perspectiva positiva.

A nova informalidade, agora, chega revestida por ares de permanência, ou seja, nessa nova roupagem, não se questiona mais as perdas de direitos trabalhistas e sociais, mas valorizam-se os ganhos. O status de trabalhador vai perdendo espaço para o de proprietário, ser patrão de si mesmo torna-se a ideologia do momento (Araújo; Oliveira, 2020, p.121).

Quando as mulheres se tornam proprietárias, num contexto de precariedade em que o trabalho subcontratado é o mais usual e são as mulheres, em sua maioria, que ocupam essas funções, cria-se uma hierarquia entre as próprias mulheres.

\section{CONSIDERAÇÕES FINAIS}

As duas experiências produtivas que buscamos trazer para dialogar sobre as assimetrias de gênero presentes no trabalho apresentam aspectos interessantes que problematizam os termos em que as mesmas se dão. Se, por um lado, a produção no Polo de Confecções (PE) e em Jardim de Piranhas (RN) reafirmam as iniquidades clássicas presentes na divisão sexual 
do trabalho e no patriarcado, há, também, novos elementos que alteram esse padrão. Assim, uma primeira questão a ser ressaltada é o fato dos dois territórios produtivos serem localizados no Nordeste brasileiro e se constituírem combinando elementos endógenos próprios das relações sociais ali estabelecidas com o desenvolvimento de uma atividade industrial que cresce conservando suas características marcadamente familiar, domiciliar precária e informal.

A origem rural e feminina desses espaços produtivos também é algo que os aproxima. Todas as mulheres entrevistadas começaram a trabalhar ainda na adolescência, sendo que algumas, por residirem inicialmente na área rural, também dedicavam-se às atividades agrícolas de subsistência, além das atividades domésticas, que sempre fizeram parte de suas trajetórias de vida, inicialmente na casa dos pais e, depois de casadas, em suas próprias casas. Através dos relatos, tivemos uma noção de como é estruturada a vida das trabalhadoras, desde as dificuldades enfrentadas através da dupla jornada de trabalho, bem como os demais altos e baixos momentos vividos, suas alegrias, suas conquistas, seus sonhos, seus medos, e suas angústias. Vimos também como as desigualdades de gênero se produzem e reproduzem cotidianamente no ambiente doméstico, assim como nos alertou Saffioti, ainda nos anos 60.

A divisão sexual do trabalho tem uma centralidade em ambas as experiências, seja reforçando os lugares clássicos que homens e mulheres ocupam na produção e na reprodução, seja apresentando questões novas. Assim como a realidade estudada por Leite (2009) sobre as bordadeiras de Ibitinga, as mudanças tecnológicas na produção têxtil, em Jardim de Piranhas, que implantou os teares mecanizados no lugar dos manuais, substituiu a força de trabalho das mulheres (que historicamente ocupavam esse lugar) pela masculina. No caso do Polo, a distribuição da mão de obra dos homens se dá menos pelo avanço tecnológico e mais pela distinção construída entre "trabalho leve" x "trabalho pesado" e as habilidades próprias de um e outro sexo. Nesse aspecto, uma diferença entre as duas experiências é que, em Jardim de Piranhas, não há uma presença constante dos homens na costura, como está posta para a região do Polo do Agreste.

Ainda em relação à divisão sexual do trabalho, verificamos que as mulheres continuam tendo que se desdobrar significativamente para dar conta da dupla jornada de trabalho, pois a responsabilidade com as atividades domésticas e cuidados com os (as) filhos (as) continua em suas mãos, confirmando estudos recentes realizados pelo IBGE. Os homens seguem envolvendo-se com as atividades domésticas na condição de "ajuda", como algo que não diz respeito a eles. Observamos que, mesmo declarando-se independentes financeiramente de seus maridos, elas consideram "natural" que a mulher seja responsável pelas tarefas domésticas e cuidados com os (as) filhos (as). Essa tensão está presente na realidade dos dois espaços produtivos e explicita como as relações de poder patriarcais junto com a divisão sexual do trabalho organizam esses contextos.

Para as mulheres costureiras, o trabalho domiciliar significa a realização do sonho por mais autonomia e liberdade, uma vez que podem decidir sobre suas rotinas de trabalho e, ao mesmo tempo, conciliar as atividades de cuidado dos filhos e demais familiares. No entanto, essa liberdade e autonomia é questionável na medida em que algumas passam a depender de contratantes para exercerem suas atividades e adquirirem renda. Além disso, o fato de o trabalho ser remunerado por produtividade faz com que elas acabem intensificando suas jornadas de trabalho, a qual, em alguns casos, chega a 14 e 16 horas diárias e até 18 horas diárias se somadas às atividades domésticas.

Constatamos que na região do Polo de Confecções do Agreste Pernambucano existe uma cultura voltada para o autoempreendedorismo, ainda que o negócio seja de pequeno porte e informal, como é o caso das facções de costura. Segundo Veras de Oliveira (2013), 
ocorreu inclusive uma reelaboração discursiva, com o objetivo de mudar a percepção de produção de "Sulanca", a qual transforma a figura do "sulanqueiro" em empreendedor(a) ou empresário(a).

A autonomia é um aspecto que também está presente na produção no Polo de Jardim de Piranhas. O desejo de ser "patrão de si mesmo" é um desejo perseguido pelas trabalhadoras e trabalhadores do aglomerado produtivo. Nesse caso, o que percebemos é que essa é uma forma que contribui para que as relações de trabalho informais tornem-se perene, de acordo com o que aponta a noção de nova informalidade.

Neste sentido, observamos que velhas e antigas formas de trabalho, como é o caso da informalidade, terceirização, subcontratação e trabalho domiciliar, presentes nos dois polos produtivos, desde sua origem, no contexto atual, são reconfiguradas e passam a ser analisadas como estratégias flexíveis, necessárias para modelos de empreendedorismo locais, baseado nas necessidades de sobrevivência e marcado pela precariedade das condições de trabalho.

Recebido para publicação em 23 de julho de 2020 Aceito em 24 de novembro de 2020

\section{REFERÊNCIAS}

ㅇ ANTUNES, Ricardo. Adeus ao Trabalho? Ensaio sobre as フู metamorfoses e a centralidade no mundo do trabalho. São N Paulo: Cortez, 2000.

กิ

ARAÚJO, Angela. Maria Carneiro; AMORIM, Elaine Regina A Aguiar. Redes de subcontratação e trabalho a domicílio na ¿ indústria de confecção: um estudo na região de Campinas. Cadernos Pagu: Campinas, n. 17-18, 2002, p. 267-310.

I ARAÚJO Iara Maria; OLIVEIRA. D. R. A cidade dos teares: ¿. informalidade e subcontratação no Seridó potiguar.

§ In. LIMA, Jacob Carlos (org.) Trabalho e globalização

๓ periférica: estudos em três setores produtivos. São Paulo,

$>$ Anablume, 2020, p. 108-131.

î่

BEZERRA, Elaine Mauricio. A revolucão será feminista, ou não será! In: MARTUSCELLI, Danilo Enrico (org.). Os

స్ desafios do feminismo marxista na atualidade. Coleção marxismo21: Chapecó, 2020, p. 51-63.

"Deslocamentos" possíveis da divisão sexual do trabalho na produção de roupas no Agreste pernambucano. Anais... XVI Encontro Nacional da ABET. Salvador, 2019.

"Trabalho de mulher, trabalho de homem" no polo de confecções do agreste de Pernambuco. 2018, 199 p. Tese (Doutorado em Ciências Sociais). Programa de Pós Graduação em Ciências Sociais da Universidade Estadual de Campinas. Instituto de Filosofia e Ciências Humanas.

BIROLI, Flávia. Gênero e desigualdades: limites da democracia no Brasil. São Paulo, Boitempo, 2018.

BURNETT, A. Era o tempo do pano na porta: Instituição e desenvolvimento da Feira da Sulanca dos anos 1950 aos anos 1980. 2014. 222 p. Tese (Doutorado em Ciências Sociais). Programa de Pós-graduação em Ciências Sociais da Universidade Federal de Campina Grande, Campina Grande.

BUTLER, Judith. Problemas de gênero: feminismo e subversão da identidade. Rio de janeiro: Civilização Brasileira, 2010.

CARNEIRO, Rosalvo Nobre; GUEDES, Josiel de Alencar. "Circuitos de fluxos sócioespaciais da indústria têxtil e impactos ambientais em Jardim de Piranhas-RN". Geosul, Florianópolis, v. 28, n. 55, pp. 103-122, 2013.

FREIRE, Cláudia. Da sulanca à fábrica: configurações do trabalho no Polo de Confecções de Pernambuco, 2016. 207 p. Tese (Doutorado em Ciências Sociais) - Programa de Pós-graduação em Ciências Sociais da Universidade Federal de Campina Grande, Campina Grande.

HARTMANN, Heidi I. The unhappy marriage of Marxism and feminism: Towards a more progressive union. Capital EClass, v. 3, n. 2, p. 1-33, 1979.

HARVEY, David. A condição pós-moderna. São Paulo: Loyola, 2006.

HIRATA, Helena; KERGOAT, Danièle. A divisão do trabalho revisitada. In. MARUANI, Margaret; HIRATA, Helena. (Orgs.) As novas fronteiras da desigualdade: homens e mulheres no mercado de trabalho. São Paulo: Editora SENAC. 2003.

. Novas configurações da divisão sexual do trabalho. Cadernos de Pesquisa, v. 37, n. 132, p. 595-609, set./dez. 2007.

HIRATA, Helena. Nova divisão sexual do trabalho? Um olhar voltado para a empresa e a sociedade. São Paulo: Boitempo editorial, 2002.

KERGOAT. Danièle. A relação social de sexo: da reprodução das relações sociais à sua subversão. Pro-posições, v.13, n. 1 (37), 2002, p. 47-59.

Divisão sexual do trabalho e as relações sociais de sexo. In: HIRATA, H. et al (orgs). Dicionário Crítico do Feminismo. São Paulo: Editora Unesp, p.67- 75, 2009.

. As bordadeiras de Ibitinga: trabalho a domicílio e prática sindical. Cadernos Pagu, n.32. Campinas, p. 183214, 2009.

LEITE, Márcia de Paula. As bordadeiras de Ibitinga: trabalho a domicílio e prática sindical. Cadernos Pagu, n.32. Campinas, p. 183-214, 2009.

LIMA, Jacob Carlos; CORTELETTI, Roseli de Fátima; ARAÚJO, Iara Maria de. "Empreendedorismo e terceirização na produção de confecções: experiências no Nordeste brasileiro". Anais... In: $42^{\circ}$ Encontro Anual da ANPOCS, Caxambu.

LIMA, J.; SOARES, M. Trabalho flexível e o novo informal. Caderno CRH, Salvador, Centro de Estudos e Pesquisas em Humanidades da UFBA, n. 37, p. 163-180, jul./dez. 2002.

MARCELINO, Paulo; CAVALCANTE, Sávio. Por uma definição de terceirização. Caderno $C R H$, Salvador, Centro de Estudos e Pesquisas em Humanidades da UFBA, v. 25, número 65: 331-346, 2012.

MILANÊS, Renata. Costurando roupa e roçados: as linhas que tecem trabalho e gênero no agreste pernambucano. 2015. 136 p. Dissertação (Mestrado em Ciências Sociais) 
- Programa de Pós-graduação de Ciências Sociais em Desenvolvimento da Universidade Federal Rural do Rio de janeiro, Instituto de Ciências Humanas e Sociais.

NICHOLSON, Linda. Feminismo e Marx: integrando o parentesco com o econômico. In: BENHABIB, Seyla \& CORNEL, Drucilla (orgs), Feminismo como crítica da modernidade. Rio de Janeiro: Editora Rosa dos Ventos, 1987, p. 23-37.

NOGUEIRA, Claudia M. O trabalho duplicado: a divisão sexual no trabalho e na reprodução: um estudo das trabalhadoras do telemarketing. Coleção Trabalho e Emancipação. 1. ed. São Paulo: Expressão Popular, 2006.

PEREIRA, Ana Márcia Batista Almeida. Dinâmica FormalInformal em Lavanderias de Jeans e suas implicações nas relações de trabalho. 2018. 330 p. Tese (Doutorado em Administracão) - Programa de Pós-Graduação em Administração da Universidade Federal da Paraíba, João Pessoa.

PEREIRA, Juliana. "Empreendedoras" das confecções: um estudo sobre a implementação do MEI e o trabalho faccionado no Agreste de Pernambuco. 2019. 249 p. Tese (Doutorado em Ciências Sociais) - Programa de PósGraduação em Ciências Sociais da Universidade Federal de Campina Grande.

PEREIRA NETO, Eugênio Vital. Qualificação e Informalidade: os modos de atuação do Senai no Polo de Confecções do Agreste Pernambucano. Recife: Fundação Joaquim Nabuco, 2013.

PERROT, Michelle. As mulheres ou o silêncio da história. São Pulo: Edusc, 2005.
PISCITELLI, Adriana. Gênero: a história de um conceito. In: ALMEIDA, H. B. \&SZWAKO, J. E. (orgs). Diferenças, igualdade. São Paulo: Berlendis\&Vertecchia, 2009, p.116148.

SAFFIOTI, Heleieth. Do artesanal ao industrial: a exploracão da mulher: um estudo de operárias têxteis e de confecções no Brasil e nos Estados Unidos. Editora HUCITEC, 1981.

Rearticulando gênero e classe social: uma questão de gênero. Rio de Janeiro, Rosa dos Tempos, 1992.

. Gênero, patriarcado, violência. Fundação Perseu Abramo, 2004

SANTOS, Éverton Araújo. Cidade e indústria na tessitura do fenômeno urbano em Jardim de Piranhas/RN. 2015. 61 p. Monografia. (Bacharelado em Geografia) Universidade Federal do Rio Grande do Norte - Caicó/RN.

SCOTT, Joan. Gênero: uma categoria útil de análise histórica. In: Educação e Realidade, Porto Alegre, v.20, n.2, 1995.

SOUZA-LOBO, Elizabeth. A classe operária tem dois sexos: trabalho, dominacão e resistência. São Paulo: Editora Fundação Perseu Ảbramo, 1991.

VÉRAS DE OLIVEIRA, Roberto. O Polo de Confecções do Agreste de Pernambuco: elementos para uma visão panorâmica. In: VERAS DE OLIVEIRA, Roberto, SANTANA, Marco Aurélio (Orgs), Trabalho em territórios produtivos reconfigurados no Brasil. João Pessoa: Editora da UFPB, p. 233-278, 2013.

VINTEUIL, Fréderique. Marxismo e Feminismo. Cadernos Democracia Socialista. São Paulo: Editora Aparte, 1989. 


\section{WORK RELATIONS AND GENDER INEQUALITIES IN THE NORTHEAST TEXTILE AND CLOTHING INDUSTRY}

\author{
Elaine Bezerra, Roseli de Fátima Corteletti \\ Iara Maria de Araújo
}

The aim of this article is to analyze two realities of work, marked by flexibility and precariousness and with an intensive workforce of women in the northeastern region of Brazil. The first involves women seamstresses in household factions of the Confections Pole of the Agreste of Pernambuco State. In the second, we have the female protagonism within the textile production in the municipality of Jardim de Piranhas-RN.The sexual division of labor is central to both experiences, either by reinforcing the classic places that men and women occupy in production and reproduction, or by presenting new issues.Visits and interviews were carried out in the two productive contexts, which allowed contact with the labor experiences of women. In the first case, home work means the search for autonomy and freedom, where we also have the entry of men in sewing. In the second, women become owners of looms and the presence of men is still small. However, these factors did not have a positive impact on gender inequalities, since domestic chores remain unchanged and even with long working hours, women workers do not perceive themselves as people generated in an oppressive and dominant society and in unequal conditions at work.

KEYwORDS: Textile and clothing industry. Female work. Gender inequalities. Informality. Precarious work.

\section{RELATIONS DE TRAVAIL ET INÉGALITÉS DE GENRE DANS L'INDUSTRIE NORD-EST DU TEXTILE ET DES VÊTEMENTS}

\author{
Elaine Bezerra, Roseli de Fátima Corteletti \\ Iara Maria de Araújo
}

L'objectif de cet article est d'analyser deux réalités du travail, marquées par la flexibilité et la précarité et avec une main-d'œuvre intensive de femmes dans la région nord-est du Brésil. Le premier concerne les femmes couturières des factions ménagères du Pôle Confections d'Agreste de l'état de Pernambuco. Dans le second, nous avons le protagonisme féminin au sein de la production textile dans la municipalité de Jardim de Piranhas-RN. La division sexuelle du travail est au cœur des deux expériences, soit en renforçant les places classiques qu'occupent les hommes et les femmes dans la production et la reproduction, soit en présentant de nouvelles problématiques .Des visites et des entretiens ont été réalisés dans les deux contextes productifs, ce qui a permis un contact avec les expériences de travail des femmes. Dans le premier cas, le travail à domicile signifie la recherche d'autonomie et de liberté, où l'on a aussi l'entrée des hommes dans la couture. Dans le second, les femmes deviennent propriétaires de métiers à tisser et la présence des hommes est encore faible. Cependant, ces facteurs n'ont pas eu d'impact positif sur les inégalités entre les sexes, car les tâches domestiques restent inchangées et même avec de longues heures de travail, femmes qui travaillent ne se perçoivent pas comme des personnes générées dans une société oppressive et dominante et dans des conditions de travail inégales.

MOTS-CLÉS:Industrie textile et habillement. Travail féminin. Inégalités entre les sexes. Informalité. Travail précaire.

Elaine Bezerra - Doutora em Ciências Sociais pela Universidade Estadual de Campinas (Unicamp). Membro do Grupo de Pesquisa Trabalho, Desenvolvimento e Políticas Públicas da UFCG. Atualmente trabalha no terceiro setor como gestora de projetos sociais no estado de Minas Gerais. Em 2019, coordenou o projeto: Curso Realidade Brasileira: cultura para a transformação da sociedade numa pareceria com o Fundo Estadual de Cultura de Minas Gerais. Está na organização de dois dossiês sobre a obra de Heleieth Saffioti a serem publicados em 2021 pela Revista de Estudos Feministas (UFSC) e a Revista de Ciências Sociais Política e Trabalho (UFPB). Atua em temas como gênero, feminismo, patriarcado e trabalho. Recentemente publicou: "A revolução será feminista, ou não será” para o Dossiê: Desafios do Feminismo Marxista na atualidade do Marxismo 21.

Roseli de Fátima Corteletti - Doutora em Sociologia pela Universidade Federal da Paraíba. Professora do Departamento de Ciências Sociais Universidade Federal de Campina Grande. Integra o Núcleo de Pesquisa Trabalho, desenvolvimento e políticas públicas, desenvolvendo pesquisas na área de Reestruturação produtiva, Informalidade, terceirização, trabalho e desigualdades gênero, precarização e precariedade do trabalho. Publicações recentes: Informalidade, terceirização, subcontratação e trabalho domiciliar: as facções de costura no Polo Confeccionista de Pernambuco. In. (Org) LIMA, Jacob Carlos. Trabalho e globalização periférica: estudos em três setores produtivos. São Paulo, Anablume, 2020; LIMA, Jacob Carlos; CORTELETTI, Roseli de Fátima; ARAUJO, Iara Maria. Empreendedorismo, informalidade e terceirização na produção de confecções: experiências no nordeste brasileiro. In. (Org) LIMA, Jacob Carlos. Trabalho e globalização periférica: estudos em três setores produtivos. São Paulo, Anablume, 2020.

Iara Maria de Araújo - Doutora em Sociologia pela Universidade Federal do Ceará. Professora do Departamento de Educação da Universidade Regional do Cariri. Integrante do Programa de Mestrado Profissional em Educação da Universidade Regional do Cariri. Coordenadora do Laboratório de Estudos e Pesquisas sobre Gênero Educação, Sexualidades e Diferenças, desenvolvendo pesquisas na área de gênero e educação, violência de gênero, trabalho e gênero. Publicações recentes: ARAÚJO Iara Maria. (Et al) Queixas denúncias e conciliações: um estudo sobre a violência de gênero. Curitiba, Appris, 2019; ARAÚJO Iara Maria e OLIVEIRA. D. R. A cidade dos teares: informalidade e subcontratação no Seridó potiguar. In. (Org) LIMA, Jacob Carlos. Trabalho e globalização periférica: estudos em três setores produtivos. São Paulo, Anablume, 2020. 